\title{
DESIGN OF MULTICULTURAL BASED ISLAMIC EDUCATION MODULE: DEVELOPMENT STUDIES AT JUNIOR HIGH SCHOOLS IN RIAU PROVINCE
}

\author{
Zaitun $^{1 *}$, Nurhayati Zein ${ }^{2}$, Kasmiati $^{3}$, Musa Thahir ${ }^{4}$ \\ ${ }^{1 *, 2,3,4}$ Universitas Islam Negeri Sultan Syarif Kasim Riau, Indonesia. \\ Email: ${ }^{1 *}$ zaitun@uin-suska.ac.id, ${ }^{2}$ nurhayati.zein@uin-suska.ac.id, ${ }^{3}$ kasmiati@uin-suska.ac.id, ${ }^{4}$ musa.thahir@uin- \\ suska.ac.id
}

\begin{abstract}
Article History: Received on $24^{\text {th }}$ July 2020, Revised on $28^{\text {th }}$ August 2020, Published on $19^{\text {th }}$ September 2020
\end{abstract}
\begin{abstract}
Purpose of the study: This study aims to produce a character-based multicultural education module that is valid and practical in the teaching of Islam in SMP Riau Province.

Methodology: The model used in this research development is the Borg and Gell model but only to the seventh stage, namely: (1) potential and problems, (2) data collection, (3) product design, (4) design validation, (5) design revision, (6) product trials, and (7) product revisions. The research instruments used in this article are validation sheets (aspects of validity), teacher and student assessment sheets (aspects of practicality). Data was collected, using interviews, observations, questionnaires.
\end{abstract}

Main findings: This article produces a product in the form of a multicultural-based PAI module that is valid in the material aspect (4.15), and valid in the technological aspect (3.98), and practical (3.62). This means that the developed multicultural-based PAI module has met valid and practical criteria so that it can be used in the learning process.

Applications of this study: This research is useful for the development of science, especially in the theoretical implementation of module development in multicultural-based Islamic Religious Education subjects which specifically provide examples of practical and systematic steps in the development of teaching materials to improve the quality of Islamic Religious Education in schools/madrasas.

Novelty/Originality of this study: This research produces multicultural PAI-based modules that provide policy recommendations and values for policymakers and educators to respond and accommodate multiculturalism in Indonesia and develop multicultural-based PAI learning modules at all levels of education.

Keywords: PAI Learning Modules, Islamic Religious Education, Multiculturalism, Validity, Practicality, Learning Process.

\section{INTRODUCTION}

Department of Islamic Education, Faculty of Tarbiyah and Teacher Training Sultan Syarif Kasim Riau State Islamic University is a formal education unit of tertiary institutions organized to realize the goals of national education and is designed to prepare professional professionals who are reliable and have professional abilities in the field of Islamic religious education. By the objectives of national education and Islamic teachings to meet guidance, improving the quality of education is an important requirement. One form of education that is very important to be included in every learning process in educational institutions, especially in this case learning in junior high schools, is multicultural education. Multicultural education is education that highly values differences and always creates freedom in which every culture can express (Saragih et al., 2018). Furthermore, multicultural education is the process of instilling a way of life that respects, is sincere, and is tolerant of a plural society (Anggraini et al., 2015). With multicultural education, it is expected that the mental flexibility of the nation faces the conflict of social conflicts so that national unity is not easily broken and cracked. This is where the importance of educational institutions to develop a culture by the ideal moral order in the educational process which in turn can be developed and applied in the real scope of society.

As a basis for multicultural, education in Indonesia is listed in Law No. 20 of 2003 concerning the National Education System. In addition to this Law on National Education System, as evidence in the 2013 Curriculum in KI1, there is the concept of acknowledgment of religious teachings. In KI2 it carries the concept of respecting differences and cooperating, and in KI4 there is a recognition of the different abilities of each student (Syamsuhari et al., 2018). The implementation of Islamic Religious Education (IRE) in schools is one of the mandates of Law Number 20 of 2003 concerning the National Education System (Awwaliyah \& Baharun, 2018). This is clearly stated that the goal of national education is to develop the potential of students to become human beings who believe in and be devoted to God Almighty, have a noble, healthy, knowledgeable, capable, creative, independent, and become democratic and responsible citizens. Therefore, Islamic Education has an important position in the national education system or the nation's moral education. This is because PAI is one of the strategic components in the national education curriculum that is responsible for fostering the character and personality of the Indonesian nation and is included in the compulsory content of the curriculum. 
Based on these explanations, it can be understood that PAI lessons require special expertise in managing the learning process, especially a teacher must have the ability to utilize teaching materials. But the fact is, so far very few PAI teachers have the initiative to make teaching materials, most of them still depend on textbooks and worksheets. The existing textbooks (teaching) and PAI LKS so far have been less effective in developing teaching material. These textbooks have not yet touched students 'mental, emotional, and spiritual-religious experiences and practices, so the existing textbooks are less able to help students' religious learning processes in developing competencies, namely finding meaning and integrating what is known with what should be done. These findings are reinforced by previous research which says that PAI learning activities carried out by teachers are still based on PAI learning guidelines and use PAI textbooks (Kamal \& Junaidi, 2018). Besides, teachers have not integrated multicultural education into learning, and have not yet understood the essence of multicultural education (Fatmawati et al., 2018). According to Muhaimin, the moral decline of students is caused by the overly dense religious education curriculum, which emphasizes aspects of thinking rather than a building awareness of religious diversity as a whole (Anam, 2016). Therefore, it is not surprising then that Islamic education is not functional in daily life, except for a small amount of verbal and formal activity to spend material and curriculum that has been programmed with a predetermined time limit.

Related to this problem, it is a challenge and experience for Islamic education teachers in fostering multicultural values, a spirit of mutual tolerance, and brotherhood to be able to apply multicultural values in the school's educational institutions. Because the diversity that exists with the attitude of still respecting and respecting this is what interests researchers. Seeing these conditions, the authors try to innovate in the delivery of multicultural PAI-based material through the Islamic Religious Education module. It is hoped that through the module that the author designed, students' learning motivation will increase, impress, be meaningful, and obtain optimal learning outcomes because in the learning atmosphere, students can learn more happily, without feeling overwhelmed and the teacher can also adjust to the goals to be achieved. This desire is strengthened by research which says that PAI learning achievements of students have good average grades, students always speak good words to the teacher and always say hello, students continue to always respect differences, students have been able to carry out the midday prayer and some other practices of worship (Faisal \& Ali, 2017). Learning tools that have been developed through the inculcation of multicultural values in students affect the behavior of students in their daily lives (Kamal \& Junaidi, 2018). Learning to use modules has several advantages (Lasmiyati \& Harta, 2014), that is: (1) modules can provide feedback, (2) modules establish clear learning goals, (3) modules that are designed to be interesting, easy to learn, and can answer needs will certainly cause students' motivation to learn, (4) modules are flexible, (5) cooperation can be established, and (6) remedies can be done.

Module development has been widely carried out and studied in various fields. Several previous studies developed thematic modules based on character education (Riwanti \& Hidyati, 2019); (Aisyi et al., 2013); (Amir, 2018); (Fatmawati et al., 2018); (Mudiono et al., 2017); (Troseth \& Strouse, 2017). Validate thematic modules (Yasa et al., 2018); (Lakuta, 2018); (Peeters \& Martin, 2017). Application of modules in learning (Djatmika et al., 2016). The module feasibility test is reviewed in terms of multicultural based material and terms of design.

From the explanation above, the researcher is interested in writing an article about the development of a multi-based PAI module. This is based on the reason that: (1) teaching material is an interesting and important matter to develop, because teaching material is a tool in the learning process, (2) students are more motivated, guided, and controlled in the direction of learning in the presence of teaching materials, (3) Junior high school students are quite diverse both ethnic, ethnic, and religious because this school is the most favorite and most popular school, not only at Pekanbaru city level but also throughout Riau Province, and (4) there is no teaching material in the form of multicultural-based Islamic Religious Education module which was developed in Riau Province Junior High School, so researchers are interested in donating teaching material development products that can improve the attractiveness and effectiveness of PAI learning.

\section{LITERATURE REVIEW}

\section{Valid and Practical Multi-Cultural Based Islamic Education Module}

Modules are teaching materials that are designed systematically based on a particular curriculum and are packaged in the form of the smallest learning unit and allow learning independently in a certain time unit so that students master the competencies taught. Modules are printed teaching materials that are designed to be studied independently by learning participants and also media for independent learning because they have been equipped with instructions for self-study (Susilo et al., 2016); (S.Sirate \& Ramadhana, 2017). Thus it can be understood that the reader can carry out learning activities without the presence of the teacher directly. The language, patterns, and other completeness contained in this module are arranged so that they appear to be the language of the teacher or the language of the teacher who is teaching their students, therefore this media is often called independent instructional material.

Learning with a module system is usually focused on a set of competencies that students must master so that they can carry out activities to achieve learning goals. Students are expected to do the tasks themselves in the module according to their abilities and speed. Self-determination of the speed in learning a module makes teachers have enough time to interact face to face with students to ensure a complete level of understanding of a learning experience. While the multicultural-based module implies that the module contains the planting of multicultural values in Islamic Religious Education. The values contained in Islamic education are in line with multicultural values, such as democratic values, 
justice, tolerance, and other values (Murzal, 2019). This is in line with the opinion that says that in the implementation of multicultural values in Islamic Islamic Education learning includes religious values, honesty values, tolerance values, democratic values, unity values, and values of justice (Anam et al., 2019). Furthermore, multicultural values in religious education which include aspects of faith, shari'a, and moral aspects that reflect the attitude of good and tolerant Muslim people in their daily lives (Araniri, 2019). From these values, it will shape a person into someone who respects differences, respects the beliefs or beliefs of others, behaves well with everyone, and can live side by side with people of different ethnicities, religions, races, and cultures.

Through research, development is expected to produce a quality product. In developing this teaching material, the product produced is in the form of multicultural PAI-based modules. Product quality in this study is seen from the validity and practicality. Validity is a measure that shows the level of accuracy, accuracy, and validity of an instrument. A product that can be used by its purpose requires a validity test. Validity is an assessment of the design of a product. Product design validation is an activation process to assess whether it is appropriate and whether the product design is more effective than the old one or not (Fransisca \& Putri, 2019). Design validation is a process of activities aimed at assessing whether a product design, in this case, a new work system, will rationally be more effective than the old one or not (Hanafi, 2017). Therefore, there is no validity is generally accepted for all measurement purposes. A measuring instrument is usually only a valid measure for one specific purpose. A tool is called valid if the tool can evaluate what should be evaluated (Setyawati et al., 2017). Accordingly, the measuring instrument used in this study is a multicultural PAI-based module. A development result (product) is said to be valid if the product is based on content validity and all components of the learning product are consistently related to each other. From this description, it can be concluded that the learning module is said to be valid if the PAI module is based on a multicultural developed based on theoretical rationale and is related consistently and can evaluate what should be evaluated. Besides having to meet valid criteria, the product developed must also be practical. Practicality is the level of convenience experienced by educators in teaching students by using a product or teaching material. This ease is also experienced by students in absorbing learning material. Nieveen argues that practicality is a criterion for the quality of learning devices in terms of the ease of teachers and students using the learning tools developed (Slamet et al., 2018). Practicality is the level of usage or ease of teaching materials for use by students (Agustyaningrum, 2015). Learning devices are said to be practical if the teacher and students consider the learning device to be easy to use and according to the researcher's plan (Purboningsih, 2015). In this study, multicultural-based PAI modules that have been developed are said to be practical if experts and practitioners state that theoretically that multicultural-based PAI modules can be applied in the field and the level of implementation is included in both categories.

In addition to meeting valid criteria, modules that are the product of the development result must also meet practical criteria. Modules have high practicality if they are practical and easy to administer. The practicality test instrument used was the practicality test instrument according to students. Practicality test instruments according to students are also arranged based on appropriate indicators to see the use of materials in learning. The practicality test instrument contains aspects that will be assessed for its implementation in learning. These aspects are arranged based on the application of multicultural PAI-based modules. Indicators of practicality are the use of time, use of books, and benefits (Saputra \& Ekawati, 2017). Nieveen said that about the development of learning materials, it can be presumed that Nieveen measured the level of practicality in terms of whether and other experts considered that the material was easy and could be used by Widyaiswara and training participants (Rochmad, 2012). Furthermore, the practicality of learning tools is seen from several aspects, namely the ease of use of learning tools for teachers and students, the time required, the readability of the devices, and the presentation of the learning tools developed in the learning process in class (Revita, 2017). Therefore, a multicultural PAI-based module is said to be practical if students can use the module easily. Thus it can be understood that teaching materials are said to be practical if the teaching materials meet aspects of practicality, which can be used easily by teachers and students as well as the level of implementation in both categories.

\section{METHODOLOGY}

The type of research used in this article uses research and development with the Borg and Gell development model modified by Sugiyono. This research step is only carried out up to the seventh step which includes: (1) potential and problems, (2) data collection, (3) product design, (4) design validation, (5) design revision, (6) scale product trial minor, and (7) product revisions.

\section{Research Instrument}

The quality of multicultural-based PAI modules is determined through expert, teacher, and student assessment. Before the module is used in class, the module is evaluated through expert assessment and then the practicality test of the module is done through the assessment of the teacher and students. The instrument used for expert assessment, teacher, and student responses was a questionnaire. Expert judgment was given by two experts in PAI education. The results of the expert assessment were revised according to expert advice. The questionnaire for expert assessment covers two aspects, namely the material and technology aspects which consist of, namely the appropriateness of the content, presentation of material, language, appearance, and feasibility of the module. The questionnaire was developed using a Likert scale, which is $1-5$. Qualitatively, $5=$ Very Valid, $4=$ Valid, $3=$ Enough Valid, $2=$ Invalid, and $1=$ Invalid. The questionnaire for teacher and participant responses contained several statements about the ease of use of the module, 
appearance, readability, and presentation. Students are asked to choose answers such as "Strongly Agree" (4), "Agree" (3), "Disagree" (2), and "Strongly Disagree" (1).

\section{Data analysis technique}

Analysis of the data used is a descriptive technique using SPSS version 23.00 for Windows. Evaluation scores for each aspect given by experts are averaged. The average score is interpreted according to the quality classification in Table 1. This classification is constructed using the ideal average score (Xi) and the ideal standard deviation score (SDI) as the basis (Widodo, 2016). For the questionnaire responses of teachers and students, the answers of teachers and students were converted to quantitative scores (1-4) on each average score for each aspect. The scores of each aspect are interpreted according to the classification in Table 1 and Tabel 2.

Table 1: Conversion of Actual Average Score to Qualitative Criteria (5 Scale)

\begin{tabular}{llll}
\hline No & Score & Score Interval & Criteria \\
\hline 1 & $\bar{X}>\bar{X}_{i}+1.8 S D i$ & $\bar{X}>4.2$ & Very Valid \\
\hline 2 & $\bar{X}_{i}-0.6 S D i<\bar{X} \leq \bar{X}_{i}+0.6 S D i$ & $3.4<\bar{X} \leq 4.2$ & Valid \\
\hline 3 & $\bar{X}_{i}+0.6 S D i<\bar{X} \leq \bar{X}_{i}+1.8 S D i$ & $2.6<\bar{X} \leq 3.4$ & Quite Valid \\
\hline 4 & $\bar{X}_{i}-1.8 S D i<\bar{X} \leq \bar{X}_{i}-0.6 S D i$ & $1.8<\bar{X} \leq 2.6$ & Less Valid \\
\hline 5 & $\bar{X} \leq \bar{X}_{i}-1.8 S D i$ & $\bar{X} \leq 1.8$ & Invalid \\
\hline
\end{tabular}

Source: (Wirjawan et al., 2020)

Table 2: Conversion of Actual Average Score to Qualitative Criteria (4 Scale)

\begin{tabular}{llll}
\hline No & Score & Score Interval & Criteria \\
\hline 1 & $\bar{X}>\bar{X}_{i}+1.8 S D i$ & $\bar{X}>4.2$ & Very Practical \\
\hline 2 & $\bar{X}_{i}-0.6 S D i<\bar{X} \leq \bar{X}_{i}+0.6 S D i$ & $3.4<\bar{X} \leq 4.2$ & Practical \\
\hline 3 & $\bar{X}_{i}+0.6 S D i<\bar{X} \leq \bar{X}_{i}+1.8 S D i$ & $2.6<\bar{X} \leq 3.4$ & Quite Practical \\
\hline 4 & $\bar{X}_{i}-1.8 S D i<\bar{X} \leq \bar{X}_{i}-0.6 S D i$ & $1.8<\bar{X} \leq 2.6$ & Less Practical \\
\hline 5 & $\bar{X} \leq \bar{X}_{i}-1.8 S D i$ & $\bar{X} \leq 1.8$ & In Practical \\
\hline
\end{tabular}

Source: (Wirjawan et al., 2020)

\section{RESULT AND DISCUSSION}

In developing this learning module, the development procedure carried out consisted of seven stages. The following describes the seven stages of developing learning modules with the Borg and Gell model.

\section{Potential and Problem Stage}

The researcher conducted the potential and problem stages to analyze the module development needs using three ways, namely: interviews, and documentation. By using these two methods, information is obtained that: 1) there are no teaching materials in the form of modules, and,2) teaching materials used are still inadequate as teaching materials and the unavailability of teaching materials that have multicultural basis specifications. Departing from the above findings, it is necessary to develop effective and interesting teaching materials as well as provide convenience in conducting assessments that measure cognitive, affective, and psychomotor aspects. The development of multicultural PAI-based teaching materials is urgently needed and is needed to overcome these obstacles.

\section{Data Collection Stage}

At this stage, the activities carried out are collecting data that can be used as a source of module making and the preparation of teaching materials collected from various sources or references. Sources or references for the development of multicultural-based PAI modules are obtained from relevant sources including 1) Book of Islamic Education Teachers for SMP/MTs grade XI (2013 Curriculum); 2) Class XI Islamic Junior High School Islamic Education Student Book (Curriculum 2013); and 3) Teacher's Worksheet for Enrichment Handling for Class IX Teachers. In addition to books/references and curriculum, it also uses Photoshop and Paints software, which is a tool for researchers to develop multicultural PAI-based modules to be better.

\section{Product Design Stage}

At this stage, a multicultural PAI-based module is designed. The multicultural PAI module product design phase consists of three main stages, including material preparation, initial product design, and initial product format development. At the material preparation stage, the material compiled in the multicultural PAI-based module is material compiled and developed by the researcher himself because there are no modules or teaching materials for PAI subjects. The material in this multicultural-based PAI module is compiled and developed through the process of compiling material for one subject matter by using several main references and supporters so that researchers can present these materials during one subject matter with three learning activities. In addition to the material, at this stage, the learning objectives are also 
arranged. The learning objectives described are adopting the 2013 Curriculum content standards for grade IX junior high school semester I. Learning objectives developed include Core Competencies (KI), Basic Competencies (KD), and indicators developed by inserting multicultural education values as formulated by H.A.R. Tilaar namely (1) love of peace, (2) love of wisdom, (3) inclusive life attitudes, (4) respect for plurality, (5) clever-clever, (6) energetic-creative, (7) responsive to democratic societies, ( 8) usability, (9) noble character, and (10) good manners. Furthermore, the researchers developed a success measuring instrument developed by the objectives achieved and the main points of learning material presented to students. The measured aspect is the competencies of the students, which are expressed in basic competencies and indicators as a result of student learning activities. The development of this success measurement tool consists of assessment standards, assessment instruments, assessment procedures, components to be analyzed, and ways of calculating grades. At this stage, a manuscript that contains information about the writing strategy is detailed and clear as a guideline for writing teaching materials. The writing design has outlined in this paper contains the identity, identification of students' needs and characteristics, product development specifications, and module framework. At the initial product design stage, the results of the analysis of teaching materials show the worksheets/teaching materials used by students have not been able to facilitate students to construct their knowledge. Researchers design multicultural PAI-based modules so that they can facilitate students in conducting investigations. The researcher designed a module on PAI subjects for 1 main subject consisting of a cover, instructions for using the module, a brief description of the subject, the contents of the material, summary, glossary, and assessment sheet. In addition, at this stage, a learning module validation sheet was also developed, and a teacher and student response questionnaire validation sheet was developed. At the initial product format development stage, the presentation of the results of the development of multicultural PAI-based modules is a description of the development modules. Module description of the results of the development in the form of a brief description of the contents of multicultural PAI-based modules. The following will present the results of the development of multicultural-based PAI modules.

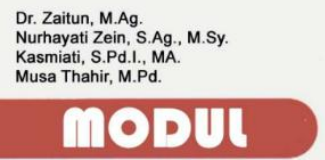

\section{Pendidikan Agama Islam Berbasis Multikultural} untuk Siswa Kelas IX SMMP Provinsi Rjau

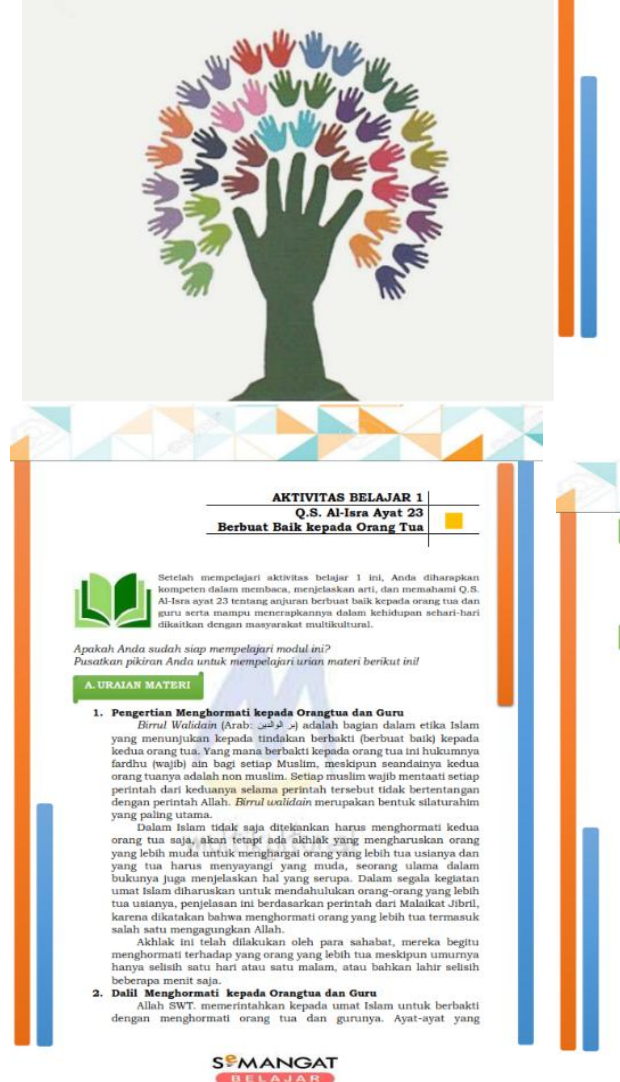
SEMANGAT
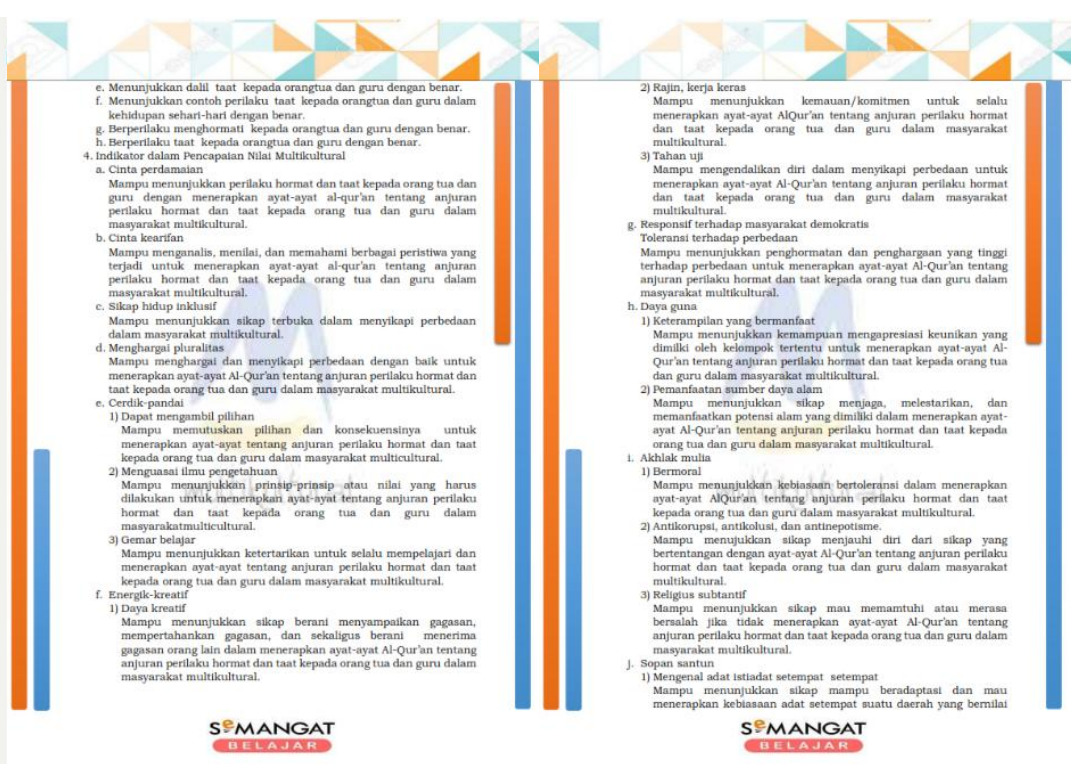

STMANGAT

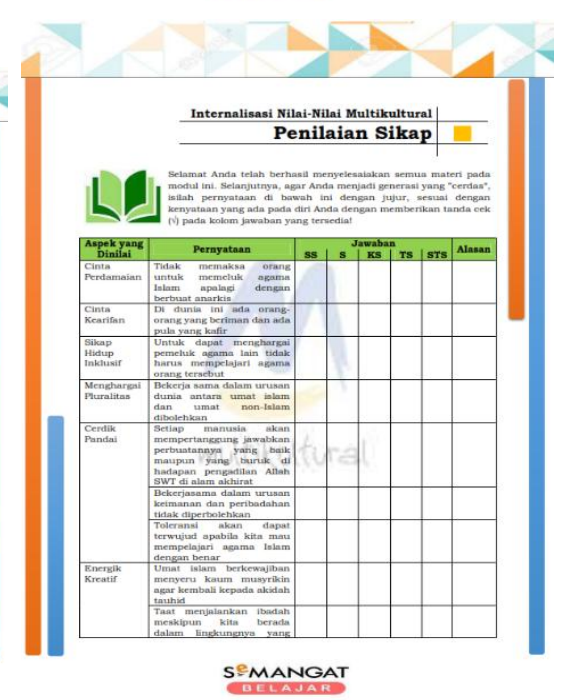

Figure 1: Results of Multicultural PAI Based Module Development

Source: Development Results Through Adobe Photoshop

(C) Zaitun et al. 


\section{Product Validation Stage}

At this stage, the researcher conducts the product validation stage by involving two experts, namely the material expert and the expert using the material and technology validation sheet. Based on the results of material validation it can be seen that the overall average aspect of the material validation is 4.15 with the category "VALID". While the results of the validation of technology experts note that the average overall aspect of technology validation is 3.98 with the category "VALID". Data validation results of technology validation by experts are presented in the following Table 3.

Table 3: Results of Multicultural Based PAI Module Material and Technology Validation

\begin{tabular}{llll}
\hline No. & Aspect & Mean* & Category \\
\hline A & Material Validation & & \\
\hline 1 & Content Feasibility Aspect & 4 & Valid \\
\hline 2 & The aspect of Feasibility of Presentation of Material & 4,27 & Very Valid \\
\hline 3 & The aspect Aspects of Language Feasibility & 4,19 & Valid \\
\hline Mean & & $\mathbf{4 , 1 5}$ & Valid \\
\hline B & Technology Validation & & \\
\hline 1 & Display Aspects & 3,90 & Valid \\
\hline 2 & Module Eligibility Aspects & 4,07 & Valid \\
\hline Mean & & 3,98 & Valid \\
\hline *score interval: $1-5$ & & \\
\hline
\end{tabular}

Source: Researcher's processed data, 2019

Based on table 3 above, information is obtained that the overall validation results by experts on product validation can be concluded that the multicultural PAI module has a "VALID" category so that the multicultural based PAI module and research instruments are feasible to be used in small product trials, but by making some improvements or revisions first.

\section{Product Revision Stage}

At this stage, researchers make improvements related to the advice of material and technology experts on the design of multicultural-based PAI modules that have been previously designed. Some suggestions and improvements given by experts related to the development of multicultural-based PAI modules are used as a reference to improve multiculturalbased PAI modules both in the material and technological aspects to be used. The next step is to make improvements by the existing suggestions so that multicultural-based PAI module products are suitable for use in the next stage.

\section{Trial Stage for Small Scale Products}

At this stage, researchers conducted a small-scale product trial involving 63 students in SMP Negeri 1 Kuantan Hilir and SMP Negeri 1 Tanah Merah using a multicultural-based PAI module that had been previously revised. This stage is done to ask students to provide comments and suggestions about multicultural PAI-based modules. The results of this stage are in the form of data obtained from the student assessment questionnaire which includes ease of use of modules, appearance, readability, and presentation. The results of evaluating small-scale product trials by students are presented in the following Table 4 .

Table 4: Results of a Field Trial Assessment Limited by Students (Practicality Test)

\begin{tabular}{llll}
\hline No. & Aspect & Mean* & Category \\
\hline 1 & Ease of Use in Modules & 3,56 & Practical \\
\hline 2 & Appearance Aspects & 3,52 & Practical \\
\hline 3 & Readability Aspects & 3,73 & Practical \\
\hline 4 & Presentation Aspects & 3,65 & Practical \\
\hline & Mean & 3,62 & Practical \\
\hline & *score interval: $1-5$ & & \\
\hline
\end{tabular}

Source: Researcher's processed data, 2019

Based on the results of the electronic module assessment by 63 students in Table 2 obtained an average of 3.56 for the aspects of ease of use of the module with the category "Practical", the average appearance aspect was 3.52 with the category "Very Practical", the aspect of average readability 3.73 with the category "Very Practical", and an average of 3.65 for aspects of presentation with the category "Very Practical". The average overall aspects obtained from student assessments are 3.62 with the category "Very Practical". As a whole, the multicultural PAI-based module is feasible to use in the category of "Very Practical", so that the learning web is feasible to be used in large-scale product/effectiveness testing by making revisions/improvements first. 


\section{Product Revision Stage}

Based on the results of limited field trials, obtained input, and suggestions from students. Some suggestions obtained from students in the multicultural-based PAI module have been carried out. Revisions were made to improve the multicultural PAI-based module to be more suitable for use in the next trial phase, namely the final/large-scale product trial (effectiveness test).

Based on the results of the explanation above, this study produced a valid multicultural based PAI learning module (the average overall aspect of material validation was 4.15 with the criteria "Valid"; and the overall aspect of technology validation was $3.98 \%$ with the criterion "Valid "). Thus, the learning modules developed have met valid qualifications because they have reached the minimum criteria of good (Rahayu \& Kholillah, 2018). Teaching material is said to be valid, if expert judgment shows that the development of the device is based on string theory and has internal consistency, is there is an interrelation between the components in the device being developed (Mustami \& Irwansyah, 2015). Besides, according to the Ministry of National Education that the criteria assessed by experts include a component of content eligibility, a linguistic component, a presentation component, and a graphic component. (Thahir et al., 2018). This result is also reinforced by the results of research which says that the printed PAI subjects developed are already feasible and effective for use in learning (Westomi et al., 2018). Further research also supports both research results which state that the results of the validation of the material and the design of multicultural PAI based teaching materials are valid and appropriate for use in learning (Saragih et al., 2018). This is also in Nieveen's opinion (Nieveen, 1999) which says that the validity aspect refers to whether the learning modules developed are theoretically appropriate and there is an internal consistency in each of its components. Besides, according to Nurfathurrahmah said that the learning device is said to be valid if expert judgment shows that the development of the device is based on string theory and has internal consistency, namely there is an interrelation between the components in the developed device (Mustami \& Irwansyah, 2015). Thus, it can be understood that the learning module developed is appropriate for future research needs.

In the material aspect, the validity level of this module is 4.15 with valid criteria. This module has advantages in terms of material design in the form of learning that is integrated with PPK, to instill multicultural values in students. Multicultural relates to interactions or actions taken by someone. Multicultural includes moral values, attitudes, and behaviors (Rokhman et al., 2014). Based on this, the concept of multicultural education is not taught but is included in the example of the application of values for habit formation (Fahmy et al., 2015). Educating multicultural by looking at the conditions or problems of students, learning materials, evaluation of learning. The language written in the module is adjusted to the level of understanding of students who are at the concrete operational stage. Besides, the language used in this module is the Indonesian communicative semi-formal language. One indicator of language eligibility is the use of communicative language (Apriliana, 2017). That is, the language in teaching materials prioritizes communication between writers and readers. While on the technological aspect, the module's validity level is 3.98 with valid criteria. The high level of validity from the technological aspect, because this module is designed with bright colors, an attractive writing layout and, images that support the material. In terms of graphics, the module is made feasible if the type of letters in the module is varied, consistent, and easy to read, the color of the letters for the title differs from the subtitle and contents of the module making it easier for students to remember the title, subtitle, and contents of the module (Daely, 2020). Learning will run optimally if the message/material is delivered, coherently, and interesting.

Besides, a product is said to be of quality if it meets 3 criteria, namely valid, practical, and effective. This is consistent with the opinion of Fauzan, Plomp, \& Gravemeijer in Desmaniati \& Fitriza (2019), that the criteria for getting good quality products are valid, practical, and effective. In this paper, the practicality of learning tools developed is discussed. Based on the results of the study note that multicultural-based learning modules are already practical. A good learning module should be practical. These results are in line with research that says that practical computer-based mathematics teaching materials are used in mathematics learning on the Pythagorean theorem material conducted by (Saputra et al., 2017). The module can help teachers and students interpret it and have the same equivalence with other teaching materials. The use of modules as an alternative approach to students in solving student learning problems, so that modules can be practical both by teachers and students (Kiong et al., 2012). Daryanto said that in general, the module can facilitate teachers and students in implementing learning and build effective learning communication between teachers and students (Dewara \& Azhar, 2019). This shows that the module developed can facilitate teachers and students in implementing learning. A teaching material that is developed should be able to help the organization of learning becomes more efficient to achieve the stated learning goals (Pane \& Dasopang, 2017). The practicality of the learning device has been achieved if the teacher can use the learning device and most students give positive responses (Zaini, 2015). This is in line with the opinion of Plomp and Nieveen that a product can be said to be practical if the product can realistically be used (Plomp \& Nieveen, 2007).

Based on the results of validation and practicality shows that this multicultural-based PAI learning module has fulfilled the valid and practical module requirements. The criteria used to assess practicality in the development of this module is the implementation of learning to use multicultural PAI based learning modules. In assessing the practicality of this module, data is collected through a questionnaire with teachers and students. This shows that multicultural-based PAI learning modules are valid and practical. The development of multicultural PAI based learning modules conducted in 
this study is one of the efforts to develop teaching materials on PAI subjects, especially in schools. Therefore, this multicultural PAI based learning module is very well used and is a solution to help students and teachers in PAI learning aimed at improving student learning outcomes and character in problem-solving.

\section{CONCLUSION}

Based on the formulation of the problem, the results of data analysis and discussion in this article, the following conclusions can be drawn. First, the results of the validation of the overall learning module from experts have an average of all aspects of material validation is 4.15 with the criteria "Valid"; and the average overall aspect of technology validation is 3.98\% with the criteria "Valid", so the learning modules and research instruments are feasible to be used in product trials. Second, the learning module has an average of all aspects obtained from the student's assessment of 3.62 with the criteria of "Practical". Thus, this article has produced a development product in the form of a multicultural PAIbased learning module that is valid and feasible to use, according to needs and follows existing rules and can provide an attraction so that students can absorb the contents of learning material more optimally.

\section{LIMITATION AND STUDY FORWARD}

This study uses a development model adopted by Sugiyono but is only limited to the small-scale product trial stage and product revision. This research was conducted in two junior high schools in Riau Province using a data collection instrument in the form of a questionnaire given to teachers and students. Therefore, the use of subjects and trial time in this development is very limited. By looking at these limitations, it is necessary to have further development research to the stage of large-scale product testing with many subjects, and repeated trials to obtain a better level of product effectiveness and efficiency.

\section{ACKNOWLEDGEMENT}

This research was conducted with the cooperation and support of university leaders and LPPM UIN Sultan Syarif Kasim Riau as well as SMP Negeri 1 Kuantan Hilir and SMP Negeri Tanah Merah in helping to make this research successful and effective.

\section{AUTHORS CONTRIBUTION}

Zaitun provided ideas and direction and made improvements to the study. Nurhayati Zein collected data and refined the language of research. Kasmiati collected data and looked for literature from previous research as a reference. Musa Thahir makes the data analysis process, integrates data and references, and is responsible for writing scientific articles.

\section{REFERENCES}

1. Agustyaningrum, N. (2015). Mengembangkan Keterampilan Berpikir Tingkat Tinggi Dalam Pembelajaran Matematika SMP. Jurnal Phytagoras, 4(1), 39-46.

2. Aisyi, F. K., Elvyanti, S., Gunawan, T., \& Mulyana, E. (2013). Pengembangan Bahan Ajar TIK SMP Mengacu Pada Pembelajaran Berbasis Proyek. INVOTEC, 9(2), 117-128. https://doi.org/10.17509/invotec.v9i2.4861

3. Amir, M. F. (2018). Perangkat Pembelajaran Berbasis Masalah Kontekstual Untuk Meningkatkan Kemampuan Metakognisi Siswa Sekolah Dasar. Journal of Medives: Journal of Mathematics Education IKIP Veteran Semarang, 2(1), 117-128. https://doi.org/10.31331/medives.v2i1.538

4. Anam, A. K., Mansur, R., \& Sulistiono, M. (2019). Penanaman Nilai-Nilai Multikultural Dalam Pembelajaran Pendidikan Agama Islam di SMP Islami Ma'arif 02 Janti Malangi. VICRATINA: Jurnal Pendidikan Islam, 4(1), 65-71.

5. Anam, C. (2016). Pengembangan Bahan Ajar PAI dengan Model Pendidikan Berparadigma Profetik. Al-Ta'dib, 6(1), 72-86.

6. Anggraini, N. D., Sudjarwo, \& Jaya, M. T. B. . (2015). Pengembangan Modul Sosiologi Berbasis Multikultural. Jurnal Studi Sosial, 3(3), 1-14.

7. Apriliana, Y. (2017). Kelayakan Isi dan Bahasa Buku Ajar Bahasa Indonesia Sekolah Menengah Pertama Kelas VIII Kurikulum 2013 Edisi Revisi 2017 Penerbit Kementerian Pendidikan dan Kebudayaan. Jurnal Pend. Bahasa Dan Sastra Indonesia-S1, 7(6), 704-713. https://doi.org/10.24114/bss.v7i4.11739

8. Araniri, N. (2019). Nilai-nilai multikultural dalam pendidikan agama islam. Al-Mau'izhoh, 1(1), 1-11.

9. Awwaliyah, R., \& Baharun, H. (2018). Pendidikan Islam Dalam Sistem Pendidikan Nasional (Telaah Epistemologi terhadap Problematika Pendidikan Islam). Jurnal Ilmiah DIDAKTIKA, 19(1), 34-49. https://doi.org/10.21154/cendekia.v12i1.370

10. Daely, B. (2020). Pengembangan Modul Pembelajaran Bahasa Indonesia Pada Materi Menyusun Resensi untuk Meningkatkan Aktivitas Belajar Siswa Kelas XI SMA. Jurnal Education and Development, 8(2), 304-311.

11. Desmaniati, E., \& Fitriza, R. (2019). Praktikalitas Perangkat Pembelajaran Transformasi Geometri Berbasis Flipped Classroom Pada Peserta Didik Kelas XI SMAN 1 Padang. Math Educa Journal, 3(1), 1-12. https://doi.org/10.15548/mej.v3i1.231

12. Dewara, N., \& Azhar, M. (2019). Validitas dan Praktikalitas Modul Larutan Penyangga Berbasis Guided Discovery dengan Mengunakan Tiga Level Representasi Kimia untuk Kelas XI SMA. EduKimia Journal, 1(2), $16-22$. 
13. Djatmika, E. E. T., Nilasari, \& Santoso, A. (2016). Pengaruh Penggunaan Modul Pembelajaran Kontekstual terhadap Hasil Belajar Siswa Kelas V Sekolah Dasar. Jurnal Pendidikan: Teori, Penelitian, Dan Pengembangan, 1(7), 1399-1404.

14. Fahmy, R., Bachtiar, N., Rahim, R., \& Malik, M. (2015). Measuring Student Perceptions to Personal Characters Building in Education: An Indonesian Case in Implementing New Curriculum in High School. Procedia Social and Behavioral Sciences, 211, 851-858. https://doi.org/10.1016/j.sbspro.2015.11.112

15. Faisal, M., \& Ali, S. N. (2017). Penerapan Bahan Ajar Mata Pelajaraan Pendidikan Agama Islam Berbasis Multikultural. ISTIQRA', 5(1), 9-16.

16. Fatmawati, L., Pratiwi, R. D., \& Erviana, V. Y. (2018). Pengembangan Modul Pendidikan Multikultural Berbasis Karakter Cinta Tanah Air dan Nasionalis pada Pembelajaran Tematik. Scholaria: Jurnal Pendidikan Dan Kebudayaan, 8(1), 80-92. https://doi.org/10.24246/j.js.2018.v8.i1.p80-92

17. Fransisca, S., \& Putri, R. N. (2019). Pemanfaatan Teknologi RFID Untuk Pengelolaan Inventaris Sekolah Dengan Metode (R\&D) (Studi Kasus: SMK Global Pekanbaru). Jurnal Mahasiswa Aplikasi Teknologi Komputer Dan Informasi, 1(1), 73.

18. Hanafi. (2017). Konsep Penelitian R \& D Dalam Bidang Pendidikan. Saintifika Islamica: Jurnal Kajian Keislaman, 4(2), 129-150.

19. Kamal, M., \& Junaidi. (2018). Pengembangan Materi Pai Berwawasan Multikultural Sebagai Upaya Menanamkan Nilai-Nilai Keberagaman Siswa Smkn 1 Ampek Nagari Kabupaten Agam. Edukasia: Jurnal Penelitian Pendidikan Islam, 13(1), 181-206. https://doi.org/10.21043/edukasia.v13i1.3798

20. Kiong, T. T., Yunos, J. B. M., Mohammad, B. Bin, Othman, W. B., Heong, Y. M., \& Mohamad, M. M. B. (2012). The Development and Evaluation of the Qualities of Buzan Mind Mapping Module. Procedia - Social and Behavioral Sciences, 59(1988), 188-196. https://doi.org/10.1016/j.sbspro.2012.09.264

21. Lakuta, P. (2018). Social Anxiety Questionnaire (SAQ): Development and Preliminary Validation. Journal of Affective Disorders, 238, 233-243. https://doi.org/10.1016/j.jad.2018.05.036

22. Lasmiyati, \& Harta, I. (2014). Pengembangan Modul Pembelajaran untuk Meningkatkan Pemahaman Konsep dan Minat SMP. PYTHAGORAS: Jurnal Pendidikan Matematika, 9(2), 161-174.

23. Mudiono, A., Akbar, S., Yasa, A. D., \& Chrisyarani, D. D. (2017). Developing Multiple IntelligencesBased Thematic Comic Module. Pancaran Pendidikan, 6(4), 115-124. https://doi.org/10.25037/pancaran.v6i4.111

24. Murzal. (2019). Nilai Multikultural Dalam Pembelajaran Pendidikan Agama Islam (PAI) di Sekolah: Studi terhadap Upaya Membina Karakter Siswa di SMKN 1 Gerung. Jurnal Penelitian Keislaman, 15(1), 66-83. https://doi.org/10.20414/jpk.v15i1.1103

25. Mustami, M. K., \& Irwansyah, M. (2015). Pengembangan Lembar Kerja Peserta Didik (LKPD) Berorientasi Pendekatan Saintifik Pada Mata Pelajaran Biologi SMA. Lentera Pendidikan: Jurnal Ilmu Tarbiyah Dan Keguruan, 18(2), 236-247. https://doi.org/10.24252/lp.2015v18n2a8

26. Nieveen, N. (1999). Prototyping to Reach Product Quality. Design Approaches and Tools in Education and Training. Springer. https://doi.org/10.1007/978-94-011-4255-7_10

27. Pane, A., \& Dasopang, M. D. (2017). Belajar dan Pembelajaran. Fitrah: Jurnal Kajian Ilmu-Ilmu Keislaman, 3(2), 333-352. https://doi.org/10.24952/fitrah.v3i2.945

28. Peeters, M. J., \& Martin, B. A. (2017). Validation of Learning Assessments: A Primer. Currents in Pharmacy Teaching and Learning, 9(5), 925-933. https://doi.org/10.1016/j.cpt1.2017.06.001

29. Plomp, T., \& Nieveen, N. (2007). An Introduction to Educational Design Research. Proceedings of The Seminar Conducted at The East China Normal University, 1-26.

30. Purboningsih, D. (2015). Pengembangan Perangkat Pembelajaran dengan Pendekatan Guided Discovery pada Materi Barisan dan Deret untuk Siswa SMK Kelas X. Seminar Nasional Matematika Dan Pendidikan Matematika UNY 2015, 467-474.

31. Rahayu, P., \& Kholillah. (2018). Validitas dan Praktikalitas Lembar Kerja Siswa Berbasis Pendekatan Kontekstual Materi Bangun Ruang Sisi Datar Pada Siswa Smp. Jurnal Ilmiah Pendidikan Matematika, 3(2), 126 - 133. https://doi.org/10.26877/jipmat.v3i2.2805

32. Revita, R. (2017). Validitas Perangkat Pembelajaran Matematika Berbasis Penemuan Terbimbing. Suska Journal of Mathematics Education, 3(1), 15. https://doi.org/10.24014/sjme.v3i1.3425

33. Riwanti, R., \& Hidyati, A. (2019). Pengembangan Modul Pembelajaran Tematik Berbasis Pendidikan Karakter di Kelas V Sekolah Dasar. Jurnal Basicedu, 3(2), 572-581. https://doi.org/10.31004/basicedu.v3i2.41

34. Rochmad. (2012). Desain Model Pengembangan Perangkat Pembelajaran Matematika. Kreano, Jurnal Matematika Kreatif-Inovatif, 3(1), 59-72.

35. Rokhman, F., Syaifudin, A., \& Yuliati. (2014). Character Education for Golden Generation 2045 (National Character Building for Indonesian Golden Years). Procedia - Social and Behavioral Sciences, 141, 1161-1165. https://doi.org/10.1016/j.sbspro.2014.05.197

36. Ruslan Saputra, Irham Falahudin, G. T. (2016). Pengembangan Bahan Ajar Matematika Berbasis Komputer untuk Siswa Kelas VIII di SMP Negeri 19 Palembang. Jurnal Pendidikan Matematika JPM RAFA, 2(249-268).

37. S. Sirate, S. F., \& Ramadhana, R. (2017). Pengembangan Modul Pembelajaran Berbasis Keterampilan Literasi. Inspiratif Pendidikan, 6(2), 316. https://doi.org/10.24252/ip.v6i2.5763

38. Saputra, N. E., \& Ekawati, Y. N. (2017). Permainan Tradisional Meningkatkan Kemampuan Dasar Anak. 
Jurnal Psikologi Jambi, 2(2), 48-53.

39. Saputra, R., Falahudin, I., \& Testiana, G. (2017). Pengembangan Bahan Ajar Matematika Berbasis Komputer untuk Siswa Kelas VIII di SMP Negeri 19 Palembang. Jurnal Pendidikan Matematika RAFA, 2(2), 249-268.

40. Saragih, S., Sinaga, A. I., \& Mardianto. (2018). Pengembangan Bahan Ajar PAI Berbasis Multikultural di SMP Negeri 17 Medan. Edu-Religia, 2(1), 140-157.

41. Setyawati, R. D., Happy, N., \& Murtianto, Y. H. (2017). Instrumen Angket Self-Esteem Mahasiswa ditinjau dari Validitas dan Reliabitas. Phenomenon, 7(2), 174-186. https://doi.org/10.21580/phen.2017.7.2.1932

42. Slamet, J., Subchan, W., \& Prihatin, J. (2018). Development of Real Questing Learning Model for Biology Learning in Senior High School. International Journal of Advanced Research, 6(7), 212-218. https://doi.org/10.21474/IJAR01/7355

43. Susilo, A., Siswandari, \& Bandi. (2016). Pengembangan modul berbasis pembelajaran saintifik untuk peningkatan kemampuan mencipta siswa dalam proses pembelajaran akuntansi siswa kelas XII SMAN 1 Slogohimo 2014. Jurnal Pendidikan Ilmu Sosial, 26(1), 50-56.

44. Syamsuhari, Suharsono, N., \& Tegeh, M. (2018). Pengembangan Modul Pendidikan Agama Islam Berbasis Multikultural di SMA. Jurnal Teknologi Pembelajaran Indonesia, 8(3), 45-54. https://doi.org/10.23887/jtpi.v8i3.2265

45. Thahir, M., Roza, Y., \& Murni, A. (2018). Validity of Learning Website of Kapita Selekta Mathematics Course at UIN Suska Riau Students. Malikussaleh Journal of Mathematics Learning (MJML), 1(1), 19-25. https://doi.org/10.29103/mjml.v1i1.667

46. Troseth, G. L., \& Strouse, G. A. (2017). Designing and Using Digital Books for Learning: The Informative Case of Young Children and Video. International Journal of Child Computer Interaction, 12(1), 3-7. https://doi.org/10.1016/j.ijcci.2016.12.002

47. Westomi, J. A., Ibrahim, N., \& Sukardjo, M. (2018). Pengembangan Paket Modul Cetak Mata Pelajaran Pendidikan Agama Islam (PAI) untuk Siswa SMA Negeri 1 Wangi-wangi Kabupaten Wakatobi. Jurnal Teknologi Pendidikan, 20(2), 138-151.

48. Widodo, E. P. (2016). Evaluasi Program Pembelajaran: Panduan Praktis Bagi Pendidik dan Calon Pendidik (Saifudin Zhri Qudsy (ed.)). Pustaka Pelajar.

49. Wirjawan, J. VD, Pratama, D., Pratidhina, E., Wijaya, A., Untung, B., \& Herwinarso. (2020). Development of Smartphone App as Media to Learn Impulse-Momentum Topics for High School Students. International Journal of Instruction, 13(3), 17-30. https://doi.org/10.29333/iji.2020.1332a

50. Yasa, A. D., Chrisyarani, D. D., Akbar, S., \& Mudiono, A. (2018). Modul Komik Tematik Berbasis Multiple Intellegence untuk Siswa Kelas V Sekolah Dasar. Jurnal Pemikiran Dan Pengembangan SD, 6(2), $107-112$. https://doi.org/10.22219/jp2sd.v6i2.7148

51. Zaini, A. (2015). Pengembangan Perangkat IPA Biologi Berorientasi Hutan Mangrove untuk Siswa SMP. Seminar Nasional XII Pendidikan Biologi UNS, 134-141. 